\title{
Leaf decomposition of the macrophyte Eichhornia azurea and associated microorganisms and invertebrates
}

\author{
C. Vieira da Silva ${ }^{1,5}$, I. Bianchini Jr.2 ${ }^{2}$, J. F. Jr. Gonçalves ${ }^{3}$, R. A. Oliveira ${ }^{4}$
}

and R. Henry ${ }^{1}$

\author{
IDepartamento de Zoologia, Instituto de Biociências, Universidade Estadual Paulista “Julio de Mesquita Filho” \\ (UNESP), Botucatu (SP), Brazil \\ 2Departamento de Hidrobiologia, Universidade Federal de São Carlos (UFSCar), São Carlos (SP), Brazil \\ ${ }^{3}$ Departamento de Ecologia, Instituto de Ciências Biológicas, Universidade de Brasília (UnB), Brasília (DF), Brazil \\ ${ }^{4}$ Departamento de Bioestatística, Instituto de Biociências, Universidade Estadual Paulista "Julio de Mesquita Filho" \\ (UNESP), Botucatu (SP), Brazil \\ ${ }^{5}$ Corresponding author: cvscarol@hotmail.com
}

Keywords: Aquatic insects; Aquatic macrophytes; ATP; Ergosterol; Lake.

\begin{abstract}
The knowledge of the decomposition of macrophytes and associated organisms is important to understand ecological processes that control aquatic ecosystem metabolism. The aims of the study were: 1) to investigate the structure and composition of the aquatic invertebrate community associated with the decomposition of leaves of the macrophyte Eichhornia azurea over time; 2 ) to determine the biomass of microorganisms (fungi and bacteria) and their relationship with the associated invertebrate communities; and 3) to assess the relationship between biotic and abiotic variables and invertebrate density. To analyze the decomposition process, leaves of E. azurea were put into litter bags and incubated in Barbosa Lake, São Paulo State, Brazil. Litter bags were retrieved at seven sampling occasions during a 2.5 month period. We measured decomposition rates of leaves, and the associated communities of invertebrates, the biomass of bacteria and fungi, and biotic and abiotic variables that might be associated with the decomposition process. Significant differences were found in the densities of invertebrates. The microorganism biomass also varied significantly throughout the experiment. Fungal biomass (ergosterol concentration) was positively associated with the density of most taxonomic groups of aquatic invertebrates, as well as the total density of invertebrates and their taxonomic richness. Total invertebrate density increased during the experiment, but the taxonomic richness of invertebrates did not follow this pattern. Insecta and Crustacea densities were the main contributors to similarity within the groups formed at each sampling time. The different ways that invertebrates use detritus, such as a food source or a feeding site, as well as their feeding plasticity, may have contributed to the increase in the total invertebrate density over time as decomposition progressed. After two months and a half of macrophyte incubation the loss of E. azurea leaf biomass was less than $4.4 \%$ of the initial value. Factors such as decreasing temperature throughout the experiment, possible inhibition of microorganism growth by leachates, the predominantly oligotrophic environment and low abrasion due to the environment lentic regime may have contributed to the low rate of decomposition of E. azurea. Our results suggest that decomposition process in the present study has not begun in fact and/or macrophyte decomposition in nature is much slower than previously thought.
\end{abstract}

Abbreviations: OM-Organic Matter, AFDM-Ash Free Dry Mass, ATP-Adenosine TriPhosphate, ANOVA-ANalysis Of VAriance, NMDS-Non-metric Multi-Dimensional Scaling, SIMPER-SIMilarity PERcentages, ANOSIM-ANalysis Of SIMilarity, ERG-ERGosterol, BIO-detritus BIOmass, WT-Water Temperature, OSM-Organic Suspended Matter, TN-Total Nitrogen, T-Transparency, DN-Nitrogen in Detritus, DP-Phosphorus in Detritus.

\section{Introduction}

Plant decomposition rates in aquatic environments are controlled by multiple physical, chemical and biological processes (Sangiorgio et al. 2010). These processes may be intrinsic or extrinsic, such as the type of decomposition (e.g., aerobic or anaerobic), the enzymatic capacity of the microbial community in the degradation of organic matter, environmental variables (e.g., temperature, availability of dissolved oxygen, $\mathrm{pH}$, redox potential) and detritus quality (Bianchini Jr. et al. 2014).
The way that the biota associated with the detritus is structured may vary as a function of the succession phase, considering that changes in the colonization by individuals during the decomposition of the substrate occurs. However, the quality of the detritus influences the time of its successional process through the decay rates and also impacts the complexity of the biological interactions among the invertebrate communities (Gonçalves et al. 2004).

Generally three phases are observable in the decomposition of vascular plants in an aerobic aquatic environment. First, biomass is quickly lost due to leaching and the release 
of soluble organic and inorganic compounds after immersion. Next, the detritus is conditioned by colonizing microorganisms (fungi and bacteria) that also act in the decomposition process, as well as by invertebrates that finalize the third phase of the decomposition process through mechanical fragmentation of the detritus for feeding after the settling of the microbial community (Webster and Benfield 1986).

Energy and nutrients made available by the decomposition process favor the trophic level for detritivores (Sangiorgio et al. 2010). The autochthonous and allochthonous senescent plant organic matter found in aquatic environments is an important source of food in the trophic structure of the system. However, the energy present in plants is very often not accessible to aquatic invertebrates (Wong et al. 1998). The reason is that the chemical composition of plants may have structural compounds toxic to herbivores which make the plant matter unpalatable (Boyd and Goodyear 1971, Stripari and Henry 2002). However, the chemical composition of a plant varies with the plant structures and their functions. As a result, primary consumers generally feed on specific plant structures according to the nutritive quality they have. Leaves usually have a greater protein and non-structural carbohydrate content (i.e., sugars and starch) in comparison to stems and petioles, particularly stems, that have more structural carbohydrates (i.e., hemicellulose, lignin and fibers) (Boyd and Goodyear 1971). Like leaves, roots and rhizomes also have large percentages of non-structural carbohydrates, but smaller amounts of proteins (Boyd and Goodyear 1971).

Previous studies measuring invertebrate abundance on decomposing macrophytes have found a significant influence of macrophyte species, with species like Eichhornia azurea (Swartz) Kunth and Oxycaryum cubense (Poepp. \& Kunth) Palla having higher decomposition rates than other macrophytes. However, this study used litter bags with a relatively large mesh size $(5 \mathrm{~mm})$, which may have allowed a greater loss of detritus, thus leading to an overestimation of the decay rates (Poi et al. 2017). Although methods for estimating decomposition in streams have been standardized (Graça et al. 2005), we are not aware of studies on decomposition of macrophytes in tropical lentic systems with standard methods, for which reason further investigation is necessary (Poi et al. 2017).

Also, studies on fungi biomass quantification during macrophyte decomposition in subtropical lakes are scarce and equally needed (Carvalho et al. 2015). The role played by fungi in plant decomposition has been more commonly investigated in lotic environments (e.g., Abelho et al. 2005, Graça and Canhoto 2006, Gonçalves et al. 2007, Abelho 2009, Sales et al. 2015). In aquatic environments, fungi and bacteria are considered the main heterotrophic organisms that feed by osmotrophy from degraded plant detritus during colonization. They share the same substrate, and develop ecological interactions that can be classified either as synergetic or antagonistic. Sometimes they have influence in distinct stages of decomposition, e.g., bacteria are important in the initial stage while fungi in middle and end of the decomposition process (Gonçalves et al. 2006). However, they are morpho- logically and phylogenetically quite distinct, with differences in their ways of living and in growth aspects (unicellular bacteria and fungus hyphae). Regardless of the differences, they are important for leaf processing and, as a consequence, for ecosystem functioning (Mille-Lindblom and Tranvik 2003, Mille-Lindblom et al. 2006).

Freshwater fungi form a diverse heterogeneous set of microorganisms, composed by species from different orders, but predominantly from ascomycetes and hyphomycetes (Wong et al. 1998). They may also colonize a variety of aquatic macrophytes, such as Juncus sp., Phragmites sp., Scirpus sp. and Typha sp. (Wong et al. 1998). Regarding aquatic bacteria, a laboratory experiment on bacterioplankton dynamics during the decomposition of E. azurea identified morphotypes Spirillum, Vibrio, Coccus and Bacillus in increasing density (cells.ml-1) at most of the sampling times (Dahroug et al. 2016). However, factors such as competition may limit resources and thus control the density/biomass of these organisms, as a consequence to decay rates (Gulis and Suberkropp 2003, Dahroug et al. 2016). Further, microorganisms may compete with other organisms that use plant detritus as substrates and feeding sites, such as aquatic invertebrates.

In relation to functional trophic groups of invertebrates found during macrophyte decomposition, a predominance of predators was observed in the early stages of decomposition (Stripari and Henry 2002, Martins et al. 2011, Carvalho et al. 2015). Detritus colonizing organisms are food sources for higher trophic levels of the food chain increasing densities and richness around half-life of detritus (Gonçalves et al. 2004). However, after this period densities and richness of invertebrates in the decomposition of detritus generally decreases gradually due to habitat instability and the reduction of food availability resulting from the loss of remaining plant matter (Carvalho et al. 2015). So, it is important to understand the relationship between decaying macrophytes and the associated organisms to investigate some of the ecological processes that control the metabolism of aquatic systems (e.g., nutrient cycling, intra- and interspecific interactions, organic matter degradation, food chain, etc.).

The objectives of this study were: 1$)$ to analyze the process of decomposition of E. azurea leaves and the concomitant colonization by invertebrates, 2) to determine the fungus biomass and total microbial biomass present in detritus, as well as their relationship with the associated invertebrate fauna, and 3) to evaluate the relationship between invertebrate density and biotic and abiotic variables. We focused on decomposition of E. azurea because it is the dominant macrophyte in the study area. In addition, its morphology with large, rounded, rigid adult leaves provide a good model for macrophyte decomposition studies. As the organic matter is degraded, the amount of polyphenols stored in the tissues of E. azurea decreases and turns them more palatable (Stripari and Henry 2002). For this reason, when invertebrates colonize decomposing plant organic matter, they may benefit from the complex food source formed by dead plant tissues nutritionally enriched by associated microorganisms and the adherence of varied organic matter, which in turn 
attracts more consumers (Lancaster and Downes 2013) and predators.

We expected an increase in the taxonomic density and richness of invertebrates, and microrganism's biomass over time and a decrease at the end of the experiment due to a reduction in the substrate available for colonization and competition for space and food. We expected that invertebrate density would be positively associated with biotic variables, like the biomass of microorganisms, and abiotic variables, such as the dissolved oxygen concentration. On the other hand, we expected detritus biomass to be negatively correlated with invertebrate density.

\section{Material and methods}

\section{Study area}

This study was conducted in a marginal lake connected to the Paranapanema River at its mouth zone into the Jurumirim Reservoir in the state of São Paulo, Brazil (Fig. 1). The study region is typically an artificial wetland, since, hydrologic connectivity, as well as the river bed outflow and lateral flooding are partially controlled by the operation of the Jurumirim Reservoir dam located downstream. The system is not controlled exclusively by the rainfall regime such as in natural flooding plains (Henry 2005).

\section{Experimental design and sampling frequency}

The E. azurea decomposition experiment was carried out between April and July 2013 (end of the rainy season and beginning of the dry season). Litter bags measuring $20 \mathrm{~cm}$ $\times 25 \mathrm{~cm}$ made of 2 -mm mesh containing $20.0 \mathrm{~g}$ of E. azurea leaves previously dried at room temperature for 3 weeks were incubated $30 \mathrm{~cm}$ from the water surface tied to floaters (seven litter bags per floater) within the E. azurea macrophyte stands at four sites on Barbosa Lake (Fig. 1). One litter bag from each site was randomly collected at each sampling time ( 1 st, $3^{\text {rd }}, 7^{\text {th }}, 14^{\text {th }}, 35^{\text {th }}, 56^{\text {th }}$ and $70^{\text {th }}$ days of incubation), totaling 28 litter bags in the whole study.

The litter bags collected were placed in plastic bags in thermal boxes with ice while in the field. Later on, the leaf detritus was carefully washed with running water over a set of sieves stacked in decreasing mesh order $(0.25,0.125,0.105$ and $0.053 \mathrm{~mm}$ ) for collecting the associated invertebrate fauna. The material retained on each of the sieves was stored in plastic tubes properly labeled and containing a $70 \%$ alcohol solution and later sorted out under stereoscopic microscope and identified at different taxonomic levels (phylum, class, order, family and subfamily) based on specialized bibliographic references (Domínguez and Fernández 2009).

\section{Abiotic and biotic variables}

The following water surface variables were measured within the E. azurea macrophyte stands at each of the four lake sampling sites: dissolved oxygen (Winkler method, modified by Golterman et al. 1978), $\mathrm{pH}$ and water electrical conductivity (corrected for $25{ }^{\circ} \mathrm{C}$, according to Golterman et al. 1978), suspended matter (gravimetry, following Teixeira and Kutner 1962), water temperature (mercury thermometer), water transparency (Secchi disk), total nitrogen (Mackereth et al. 1978) and total phosphorus (Strickland and Parsons, 1960) concentration in water, and total concentration of photosynthetic pigments (Golterman et al. 1978). The total nitrogen concentrations in the remaining dry biomass were determined through acid digestion by Kjeldahl method and the total phosphorus concentrations by spectrophotometric method, also undergoing acid digestion.

Three sets of five disks (1.5-cm diameter) with five $E$. azurea leaves from each of the litter bags were prepared after the removal of the invertebrates and stored in a freezer at -20 ${ }^{\circ} \mathrm{C}$ for determination of the ash-free dry mass, total microbial biomass and fungi biomass. The remaining leaf detritus was oven dried at $\cong 50{ }^{\circ} \mathrm{C}$ to constant mass.

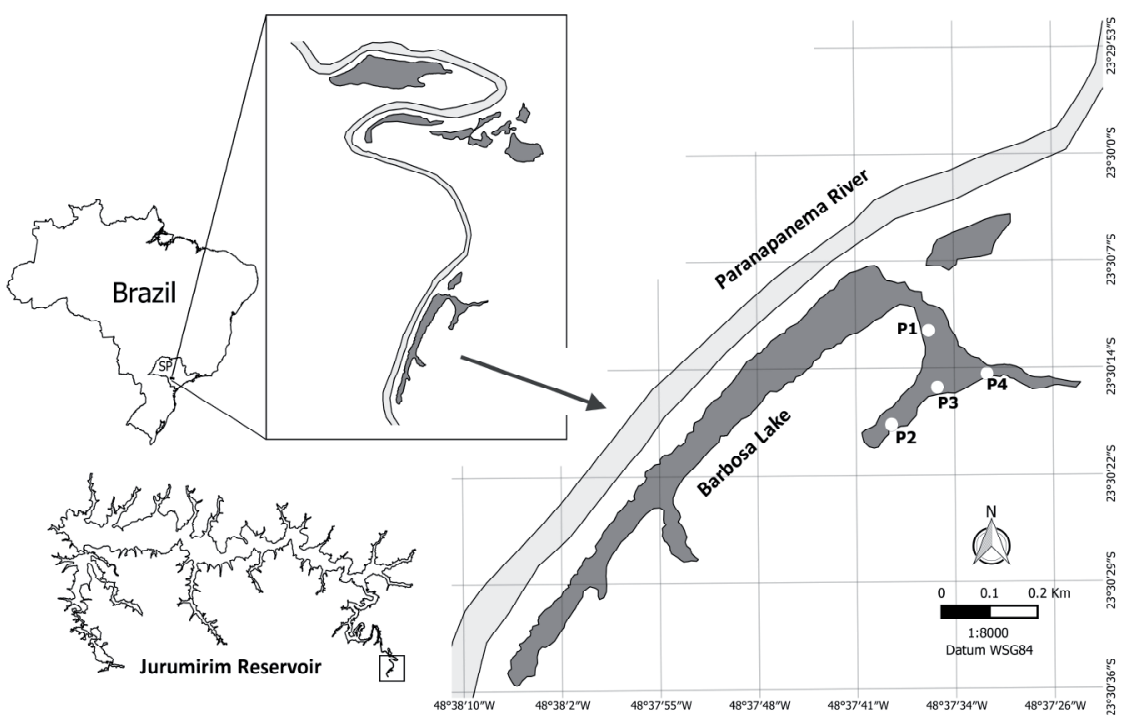

Figure 1. Study area: Barbosa Lake, marginal to the Paranapanema River at the river mouth zone into Jurumirim Reservoir (São Paulo, Brazil). 
The ash content from the set of disks was determined by burning in an oven at $500{ }^{\circ} \mathrm{C}$ for $4 \mathrm{~h}$. The detritus organic matter (OM) content was determined by difference from the total dry mass. The ash-free dry mass (AFDM) data were also used to correct the values of total biomass from the litter bags by converting it to detritus OM content alone. The carbon content of E. azurea leaf detritus was estimated as $47 \%$ of the OM content (Wetzel 1975).

The fungi biomass of the E. azurea leaf detritus was determined by extraction and quantification of ergosterol, a lipid component exclusive to the fungi cell membrane (Gessner 2005). The total microbial biomass in the detritus was determined by quantification of ATP by enzymatic activity bioluminescence (Abelho 2005).

\section{Analysis of the decomposition process}

The decomposition coefficient $(k)$ was determined by percent fitting of the mass loss to the exponential model (Equation 1, Olson 1963). Fitting was performed by nonlinear regression using the Levenberg-Marquardt iterative algorithm (Press et al. 2007). The half-life $\left(t_{1 / 2}\right)$ was calculated with Equation (2):

$W_{t}=W_{0} \times e^{-k \times t}$

where: $W_{t}=$ remaining dry mass $(\%), W_{0}=$ initial dry mass $(\%), k=$ decomposition coefficient $\left(\right.$ day $\left.^{-1}\right), t=$ time (day).

$t_{1 / 2}=(\ln 0.5) /-k$

The ATP content was determined using a $1^{\text {st }}$ order mathematical model that considered two processes simultaneously, the growth of the microorganisms and the decrease in the ATP concentration (Equation 3, Levenspiel 1974). Fitting was performed by non-linear regressions using the LevenbergMarquardt iterative algorithm (Press et al. 2007).

$A T P_{t}=A T P_{\max } \times \mu \times\left(\frac{e^{-\mu t}}{k-\mu}+\frac{e^{-k t}}{\mu-k}\right)$

where: $A T P=$ ATP concentration, $\mu=$ coefficient of increase in ATP concentration $\left(\right.$ day $\left.^{-1}\right), k=$ coefficient of decrease in ATP concentration $\left(\right.$ day $\left.^{-1}\right), t=$ time (day).

The ergosterol concentration and invertebrate abundance in the remaining detritus biomass were determined using the exponential growth model (Equation 4). The duplication time $\left(t_{d}\right)$ of biotic variables ergosterol concentration and invertebrate concentration were estimated using Equation (5) and fitted by non-linear regressions using the Levenberg-Marquardt iterative algorithm (Press et al. 2007).

$N_{t}=N_{0} \times e^{\mu \times t}$

where: $N_{t}=$ value of the biotic variable in time $t, N_{0}=$ initial value of the biotic variable, $\mu=$ growth coefficient $\left(\right.$ day $\left.^{-1}\right), t$ $=$ time (day).

$t_{d}=(\ln 2) / \mu$ where: $t_{d}=$ duplication time in days, $\ln 2=$ Neper logarithm of $2, \mu=$ growth coefficient of the biotic variable.

\section{Quantitative analysis of invertebrates}

Density (ind. $100 \mathrm{gDM}^{-1}$ ) was calculated from the total abundance of individuals present in the remaining ash-free dry mass of $E$. azurea leaf detritus for each of the seven sampling times.

The mean daily macrophyte detritus colonization rate $(x)$ by invertebrates, expressed in terms of abundance (daily variation rate of individual abundance) and richness (daily variation rate of taxonomic richness) in the successive sampling intervals, was estimated through simple derivative calculation, the function of which was invertebrate abundance and richness over time using $x_{A}=\left(A_{2}-A_{1}\right) /\left(t_{2}-t_{1}\right)(A=$ abundance and $t=$ time $)$ and $x_{R}=\left(R_{2}-R_{1}\right) /\left(t_{2}-t_{1}\right)(R=$ richness and $t=$ time). A linear regression was performed using values of simple derivate calculation for invertebrate abundance and richness over time.

\section{Statistical analysis}

The variation of the abiotic and biotic values over time were examined by Linear Mixed Models using software SAS 9.3 version (Statistical Analysis System). Data were log-transformed to improve model fit, except for water $\mathrm{pH}$ values. One statistical model was built for each biotic and abiotic variable. The random factors were considered as sampling sites and fixed factors were the successive sampling times (number of experiment days). Tukey's multiple comparison test were carried out when the variable had more than two categorical levels. The significant level for the statistical tests was $5 \%(\mathrm{p} \leq 0.05)$.

To verify possible correlations between invertebrates associated with $E$. azurea leaf detritus and their respective biotic variables and Barbosa Lake environmental variables, a Spearman's correlation coefficient matrix was calculated using the invertebrate density values found for each sampling time.

To test the similarities between leaf detritus invertebrate density on successive sampling days, Non-Metric Multidimensional Scaling analysis (NMDS) was made using the Bray-Curtis dissimilarity coefficient. The main taxa responsible for clustering shaped by the NMDS were identified by Similarity Percentage analysis (SIMPER) just for larger groups and the differences in invertebrate density by analysis of similarity (ANOSIM). All multivariate analyses were carried out with the Primer v6 program (Clarke and Gorley 2006) using square root-transformed data (Clarke and Warwick 2001).

\section{Results}

\section{Abiotic variables}

The highest water temperature was recorded at the beginning of the experiment and it fell up to the $35^{\text {th }}$ day, after which it increased at the final sampling times $\left(56^{\text {th }}\right.$ 
Table 1. Variation in mean values, standard deviation values $(\mathrm{N}=4)$ and variance analysis results (Linear Mixed Models) of Barbosa Lake environmental variables from April to July 2013. In brackets are F values and in bold significant differences ( $\mathrm{p} \leq 0.05$ ). Values with at least one similar letter present no significant differences (Tukey test; $\mathrm{p} \leq 0.05$ ).

\begin{tabular}{|c|c|c|c|c|c|c|c|c|c|}
\hline Variables/Days & Initial & $1^{\text {st }}$ & $3^{\text {rd }}$ & $7^{\text {th }}$ & $14^{\text {th }}$ & $35^{\text {th }}$ & $56^{\text {th }}$ & $70^{\text {th }}$ & $\begin{array}{c}\mathrm{F} \text { and } \mathrm{p} \\
\text { values }\end{array}$ \\
\hline Water temperature $\left({ }^{\circ} \mathrm{C}\right)$ & $\begin{array}{l}28 \\
\pm 0 \\
\text { (a) }\end{array}$ & $\begin{array}{l}26 \\
\pm 1 \\
\text { (b) }\end{array}$ & $\begin{array}{l}26 \\
\pm 1 \\
\text { (b) }\end{array}$ & $\begin{array}{l}26 \\
\pm 1 \\
\text { (b) }\end{array}$ & $\begin{array}{l}21 \\
\pm 1 \\
\text { (c) }\end{array}$ & $\begin{array}{l}19 \\
\pm 0 \\
\text { (d) }\end{array}$ & $\begin{array}{l}19 \\
\pm 0 \\
\text { (d) }\end{array}$ & $\begin{array}{l}21 \\
\pm 1 \\
\text { (c) }\end{array}$ & $\begin{array}{c}(208.90) \\
<\mathbf{0 . 0 0 1}\end{array}$ \\
\hline Dissolved oxygen concentration (mg.L-1) & $\begin{array}{c}7 \\
\pm 2 \\
\text { (a) }\end{array}$ & $\begin{array}{c}8 \\
\pm 2 \\
\text { (a) }\end{array}$ & $\begin{array}{c}8 \\
\pm 1 \\
\text { (a) }\end{array}$ & $\begin{array}{l}10 \\
\pm 2 \\
\text { (a) }\end{array}$ & $\begin{array}{c}9 \\
\pm 3 \\
\text { (a) }\end{array}$ & $\begin{array}{c}8 \\
\pm 2 \\
\text { (a) }\end{array}$ & $\begin{array}{c}7 \\
\pm 2 \\
\text { (a) }\end{array}$ & $\begin{array}{c}7 \\
\pm 1 \\
\text { (a) }\end{array}$ & $\begin{array}{l}(2.30) \\
0.0660\end{array}$ \\
\hline Oxygen saturation (\%) & $\begin{array}{l}101 \\
\pm 22 \\
(\mathrm{a}, \mathrm{b})\end{array}$ & $\begin{array}{l}110 \\
\pm 29 \\
(\mathrm{a}, \mathrm{b})\end{array}$ & $\begin{array}{l}110 \\
\pm 20 \\
(\mathrm{a}, \mathrm{b})\end{array}$ & $\begin{array}{c}124 \\
\pm 20 \\
\text { (a) }\end{array}$ & $\begin{array}{l}105 \\
\pm 38 \\
(\mathrm{a}, \mathrm{b})\end{array}$ & $\begin{array}{c}96 \\
\pm 23 \\
(\mathrm{a}, \mathrm{b})\end{array}$ & $\begin{array}{c}78 \\
\pm 23 \\
\text { (b) }\end{array}$ & $\begin{array}{l}82 \\
\pm 8 \\
\text { (b) }\end{array}$ & $\begin{array}{l}(3.75) \\
0.0086\end{array}$ \\
\hline Water $\mathrm{pH}$ & $\begin{array}{c}6 \\
\pm 0 \\
(\mathrm{a}, \mathrm{b})\end{array}$ & $\begin{array}{c}6 \\
\pm 0 \\
(\mathrm{a}, \mathrm{b})\end{array}$ & $\begin{array}{c}6 \\
\pm 0 \\
(\mathrm{a}, \mathrm{b})\end{array}$ & $\begin{array}{c}6 \\
\pm 0 \\
(\mathrm{a}, \mathrm{b})\end{array}$ & $\begin{array}{c}6 \\
\pm 0 \\
(\mathrm{a}, \mathrm{b})\end{array}$ & $\begin{array}{c}7 \\
\pm 0 \\
(b, c)\end{array}$ & $\begin{array}{c}8 \\
\pm 1 \\
\text { (c) }\end{array}$ & $\begin{array}{c}6 \\
\pm 0 \\
(\mathrm{a}, \mathrm{b})\end{array}$ & $\begin{array}{c}(6.03) \\
\mathbf{0 . 0 0 0 6 4}\end{array}$ \\
\hline Organic suspended matter (mg.L-1) & $\begin{array}{c}5 \\
\pm 2 \\
\text { (a) }\end{array}$ & $\begin{array}{c}10 \\
\pm 5 \\
(\mathrm{a}, \mathrm{b})\end{array}$ & $\begin{array}{c}13 \\
\pm 7 \\
(\mathrm{a}, \mathrm{b})\end{array}$ & $\begin{array}{c}11 \\
\pm 4 \\
(\mathrm{a}, \mathrm{b})\end{array}$ & $\begin{array}{c}12 \\
\pm 7 \\
(\mathrm{a}, \mathrm{b})\end{array}$ & $\begin{array}{c}25 \\
\pm 13 \\
(\mathrm{a}, \mathrm{b})\end{array}$ & $\begin{array}{c}45 \\
\pm 32 \\
\text { (b) }\end{array}$ & $\begin{array}{c}20 \\
\pm 22 \\
(a, b)\end{array}$ & $\begin{array}{c}(3.26) \\
0.0166\end{array}$ \\
\hline Inorganic suspended matter (mg. $\left.\mathrm{L}^{-1}\right)$ & $\begin{array}{c}3 \\
\pm 1 \\
\text { (a) }\end{array}$ & $\begin{array}{c}4 \\
\pm 2 \\
\text { (a) }\end{array}$ & $\begin{array}{c}3 \\
\pm 1 \\
\text { (a) }\end{array}$ & $\begin{array}{c}3 \\
\pm 2 \\
\text { (a) }\end{array}$ & $\begin{array}{c}4 \\
\pm 2 \\
\text { (a) }\end{array}$ & $\begin{array}{c}3 \\
\pm 2 \\
\text { (a) }\end{array}$ & $\begin{array}{c}7 \\
\pm 6 \\
\text { (a) }\end{array}$ & $\begin{array}{l}12 \\
\pm 8 \\
\text { (a) }\end{array}$ & $\begin{array}{l}(1.88) \\
0.1235\end{array}$ \\
\hline Water electrical conductivity $\left(\mu \mathrm{S} . \mathrm{cm}^{-1}\right)$ & $\begin{array}{l}33 \\
\pm 1 \\
\text { (a) }\end{array}$ & $\begin{array}{l}33 \\
\pm 1 \\
\text { (a) }\end{array}$ & $\begin{array}{l}33 \\
\pm 1 \\
\text { (a) }\end{array}$ & $\begin{array}{l}32 \\
\pm 2 \\
\text { (a) }\end{array}$ & $\begin{array}{c}36 \\
\pm 1 \\
(\mathrm{a}, \mathrm{b})\end{array}$ & $\begin{array}{l}38 \\
\pm 4 \\
\text { (b) }\end{array}$ & $\begin{array}{c}35 \\
\pm 1 \\
(\mathrm{a}, \mathrm{b})\end{array}$ & $\begin{array}{c}34 \\
\pm 2 \\
(\mathrm{a}, \mathrm{b})\end{array}$ & $\begin{array}{c}(4.83) \\
\mathbf{0 . 0 0 2 3}\end{array}$ \\
\hline Water transparency $(\mathrm{m})$ & $\begin{array}{c}1.1 \\
\pm 0 \\
(\mathrm{a}, \mathrm{b})\end{array}$ & $\begin{array}{c}1.5 \\
\pm 0 \\
(\mathrm{a}, \mathrm{b})\end{array}$ & $\begin{array}{l}1.5 \\
\pm 0 \\
\text { (a) }\end{array}$ & $\begin{array}{c}1.4 \\
\pm 0 \\
(\mathrm{a}, \mathrm{b})\end{array}$ & $\begin{array}{c}1.2 \\
\pm 0 \\
(\mathrm{a}, \mathrm{b})\end{array}$ & $\begin{array}{l}1.6 \\
\pm 0 \\
\text { (a) }\end{array}$ & $\begin{array}{l}1.5 \\
\pm 0 \\
\text { (a) }\end{array}$ & $\begin{array}{l}0.7 \\
\pm 0 \\
\text { (b) }\end{array}$ & $\begin{array}{l}(37.21) \\
<\mathbf{0 . 0 0 1}\end{array}$ \\
\hline Water depth (m) & $\begin{array}{l}1.8 \\
\pm 0 \\
\text { (a) }\end{array}$ & $\begin{array}{l}1.8 \\
\pm 0 \\
\text { (a) }\end{array}$ & $\begin{array}{l}1.8 \\
\pm 0 \\
\text { (a) }\end{array}$ & $\begin{array}{l}1.8 \\
\pm 0 \\
\text { (a) }\end{array}$ & $\begin{array}{l}1.7 \\
\pm 0 \\
\text { (a) }\end{array}$ & $\begin{array}{l}1.6 \\
\pm 0 \\
\text { (a) }\end{array}$ & $\begin{array}{l}1.8 \\
\pm 0 \\
\text { (a) }\end{array}$ & $\begin{array}{l}2.3 \\
\pm 1 \\
\text { (a) }\end{array}$ & $\begin{array}{c}(0.85) \\
0.560\end{array}$ \\
\hline Total nitrogen concentration $\left(\mu \mathrm{g} . \mathrm{L}^{-1}\right)$ & $\begin{array}{c}490 \\
\pm 141 \\
\text { (a) }\end{array}$ & $\begin{array}{c}507 \\
\pm 160 \\
\text { (a) }\end{array}$ & $\begin{array}{l}458 \\
\pm 27 \\
\text { (a) }\end{array}$ & $\begin{array}{c}487 \\
\pm 36 \\
\text { (a) }\end{array}$ & $\begin{array}{c}592 \\
\pm 110 \\
(\mathrm{a}, \mathrm{b})\end{array}$ & $\begin{array}{c}792 \\
\pm 78 \\
(\mathrm{a}, \mathrm{b})\end{array}$ & $\begin{array}{c}975 \\
\pm 364 \\
\text { (b) }\end{array}$ & $\begin{array}{c}752 \\
\pm 297 \\
(\mathrm{a}, \mathrm{b})\end{array}$ & $\begin{array}{c}(4.51) \\
\mathbf{0 . 0 0 3 3}\end{array}$ \\
\hline Total phosphorus concentration $\left(\mu \mathrm{g} . \mathrm{L}^{-1}\right)$ & $\begin{array}{l}22 \\
\pm 3 \\
\text { (a) }\end{array}$ & $\begin{array}{c}37 \\
\pm 16 \\
\text { (a) }\end{array}$ & $\begin{array}{l}25 \\
\pm 9 \\
\text { (a) }\end{array}$ & $\begin{array}{c}34 \\
\pm 15 \\
\text { (a) }\end{array}$ & $\begin{array}{l}26 \\
\pm 7 \\
\text { (a) }\end{array}$ & $\begin{array}{c}46 \\
\pm 23 \\
\text { (a) }\end{array}$ & $\begin{array}{c}46 \\
\pm 46 \\
\text { (a) }\end{array}$ & $\begin{array}{c}57 \\
\pm 24 \\
\text { (a) }\end{array}$ & $\begin{array}{l}(1.91) \\
0.1189\end{array}$ \\
\hline
\end{tabular}

and $70^{\text {th }}$ days) (Table 1). The variations in mean concentrations of dissolved oxygen between successive sampling days were minimal, in contrast to that of percent saturation (Table 1).

Water $\mathrm{pH}$, suspended material and total nitrogen for the $56^{\text {th }}$ day stood out for their high values (Table 1). Water electrical conductivity increased after the $14^{\text {th }}$ day and the highest value was recorded on the $35^{\text {th }}$ day (Table 1 ).

The smallest water transparency was recorded in the period of the highest depth value obtained in the study (Table 1). The total phosphorus concentration in water was also the greatest on the $70^{\text {th }}$ sampling day. Statistically significant differences were observed over time for almost all the environmental variables analyzed (Table 1).

\section{Biotic variables}

The greatest total pigment values were observed at the end of the experiment (from days 35 to 70), with a peak on day $56\left(222.6 \mu \mathrm{g} . \mathrm{L}^{-1}\right)$ (Fig. 2A). Statistically significant differences in time were found $(\mathrm{F}=3.71 ; \mathrm{p}=0.0091)$.
The loss of remaining E. azurea leaf biomass in the first seven days was only $1.81 \%$. The decomposition rate in the following days was low, as the mass loss during the study period was very small. On the $35^{\text {th }}$ day, the percent mass loss was the greatest, $4.4 \%$ of the initial value (Fig. 2B).

The greater ash content found on day $35(4.8 \%)$ was followed by a decrease at the end of the experiment (Fig. 3A). In contrast, the carbon content was smaller on the $35^{\text {th }}$ day $(44.9 \%)$ and increased at the end of the experiment (3B). The variations of nitrogen (3C) and phosphorus (3D) concentrations in the remaining dry biomass were small; however, both concentrations decreased at the end of the experiment.

The biomass decay coefficient of the remaining biomass of $E$. azurea leaves was extremely low, while the half-life was very high (Table 2); however, exclusion of the last two sampling times ( $56^{\text {th }}$ and $70^{\text {th }}$ days) from the model gave, $k=$ 0.00148 day $^{-1} ; r^{2}=0.52$ and $t_{1 / 2}=468$ days.

The concentration of ergosterol $\left(\mu \mathrm{g} \cdot \mathrm{g}^{-1}\right.$ AFDM - ash free dry mass) was detected only after the $35^{\text {th }}$ day of the experiment and gradually increased (Fig. 4A). On the other hand, the microbial community biomass (nmoles.g-1 AFDM) increased on the first day and decreased, mainly from days 1 
Table 2. Biomass decay $(k)$, growth $(\mu)$ and determination $\left(\mathrm{r}^{2}\right)$ coefficients for half-life $\left(\mathrm{t}_{1 / 2}\right)$ and duplication times $\left(\mathrm{t}_{\mathrm{d}}\right)$ of the models used in the analyses of the decomposition process (1), ATP content (2) and ergosterol concentration (3) and invertebrate abundance (3) in the remaining biomass of $E$. azurea leaves from Barbosa Lake in successive sampling times from April to July 2013.

\begin{tabular}{llccccc}
\hline \multicolumn{1}{c}{ Models } & $k$ & $\mu$ & $r^{2}$ & $t_{1 / 2}$ & $t_{d}$ \\
\hline (1) & Remaining leaf biomass & 0.00051 day-1 $^{2}$ & - & 0.92 & 1.359 days & - \\
(2) & $\begin{array}{l}\text { Microrganism biomass } \\
\text { (ATP) }\end{array}$ & 0.01808 day $^{-1}$ & 0.61029 day $^{-1}$ & 0.86 & 7 days & 3 days \\
(3) & $\begin{array}{l}\text { Fungal biomass (ergosterol) } \\
\text { (3) }\end{array}$ & - & 0.0261 day $^{-1}$ & 0.84 & - & 26 days \\
Quantitative increase in & - & 0.0357 day-1 $^{-1}$ & 0.82 & - & 6 days \\
\hline
\end{tabular}
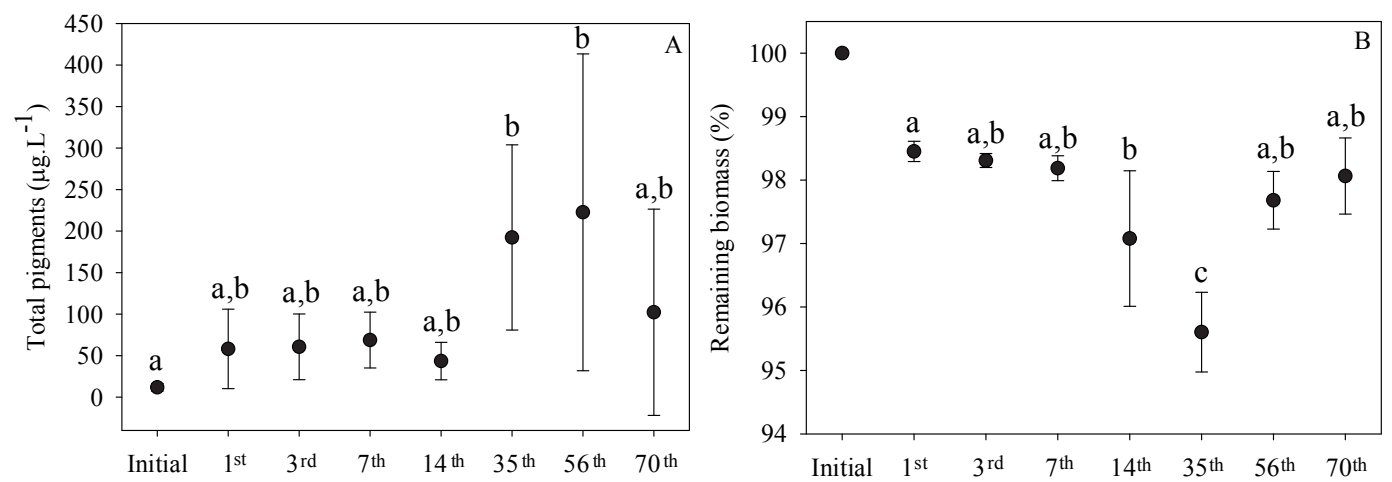

Figure 2. Mean value $(N=4)$ and standard deviation of total pigments (A) and remaining dry biomass of E. azurea leaves (B) on Barbosa Lake at successive sampling times (number of experiment days) from April to July 2013. Sampling times with at least one similar letter present no significant differences (Tukey test; $\mathrm{p} \leq 0.05$ ).
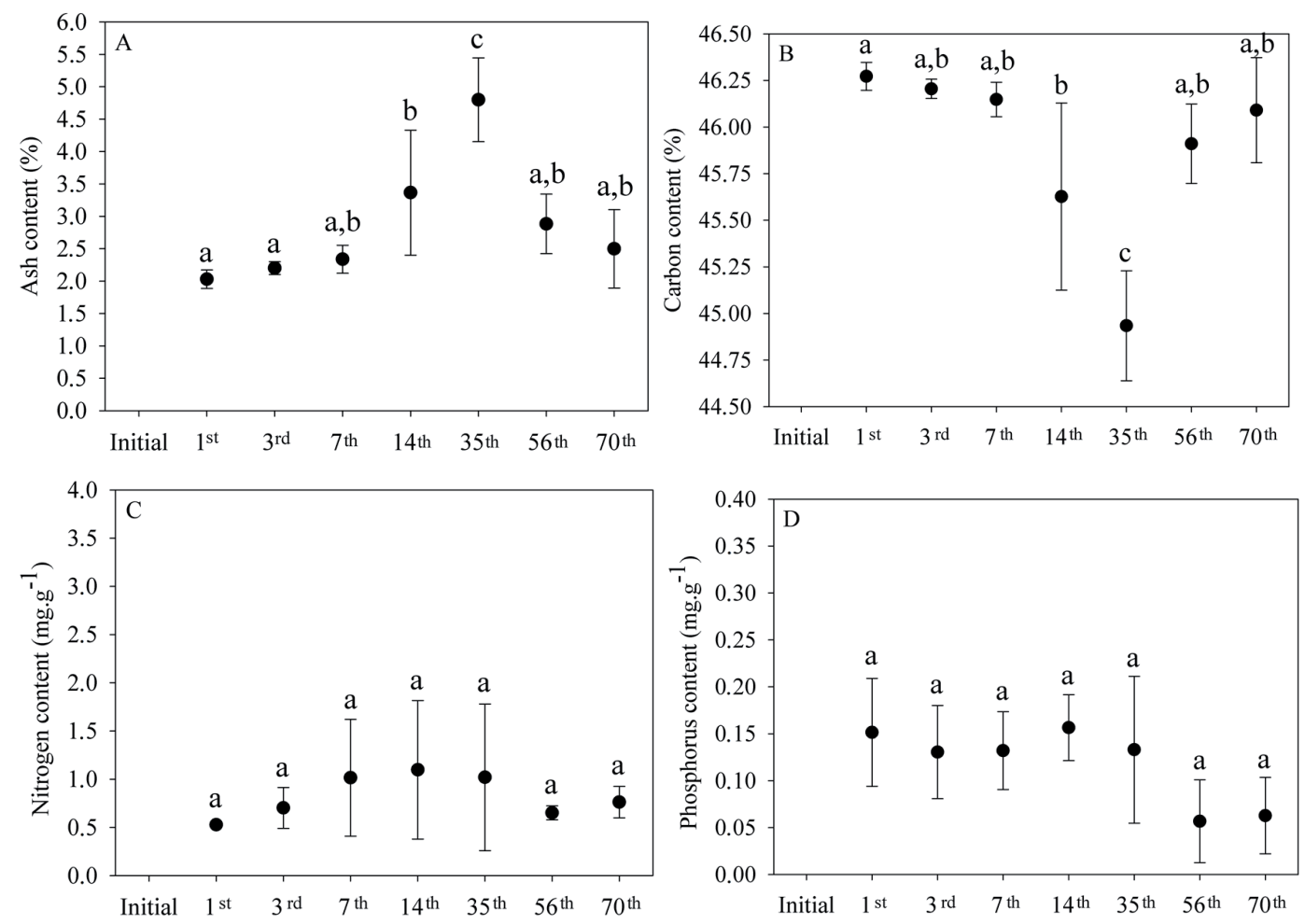

Figure 3. Mean value $(N=4)$ and standard deviation (error bar) of percent ash content $(\mathrm{A})$, carbon content $(\mathrm{B})$, nitrogen $(\mathrm{C})$ and phosphorus contents (D) in the remaining dry mass of E. azurea leaves on Barbosa Lake in successive sampling times (number of experiment days) from April to July 2013. (Note the different scales). Sampling times with at least one similar letter present no significant differences (Tukey test; $\mathrm{p} \leq 0.05$ ). 
to 7 , and slightly from days 7 to 70 (Fig. 4B). Both variables present statistically significant differences in time $(\mathrm{F}=17.95$; $\mathrm{p}=<0.001$ and $\mathrm{F}=3.17 ; \mathrm{p}=0.0265$, respectively).

Regarding the variables determined in $E$. azurea leaf detritus, the percent remaining dry biomass $(\mathrm{F}=14.29$; $\mathrm{p}<0.001)$, the percent ash content $(\mathrm{F}=13.80 ; \mathrm{p}<0.001)$, the carbon content $(\mathrm{F}=14.29 ; \mathrm{p}<0.001)$ and total phosphorus concentration $(\mathrm{F}=2.70 ; \mathrm{p}=0.0476)$, present statistically significant differences in time. The differences of phosphorus concentration between sampling days were not identified by the Tukey test.

The total density of the aquatic invertebrate community associated with E. azurea leaf decomposition increased during the experiment (Fig. 4C) and present statistically signifi- cant differences in time $(\mathrm{F}=28.16 ; \mathrm{p}<0.001)$. NMDS (Fig. 6 ) and ANOSIM analyses showed that the densities of large groups of invertebrates of the community associated with E. azurea leaf detritus were significantly different in time (ANOSIM: $\mathrm{p}=0.001$, global $\mathrm{R}=0.7$ ).

The mean daily rate of colonization of the number of invertebrate individuals peaked on the $1^{\text {st }}$ day (71 ind.day 1) and again on the $7^{\text {th }}\left(23\right.$ ind.day $\left.{ }^{-1}\right)$ and $70^{\text {th }}$ days $(28$ ind. day $^{-1}$ ) (Fig. 4D). There was no strong relationship between colonization rate and sampling times (linear regression $\mathrm{R}^{2}=$ 0.0384)

The total taxonomic richness (at large group levels) followed a pattern different from that of the density, but on the
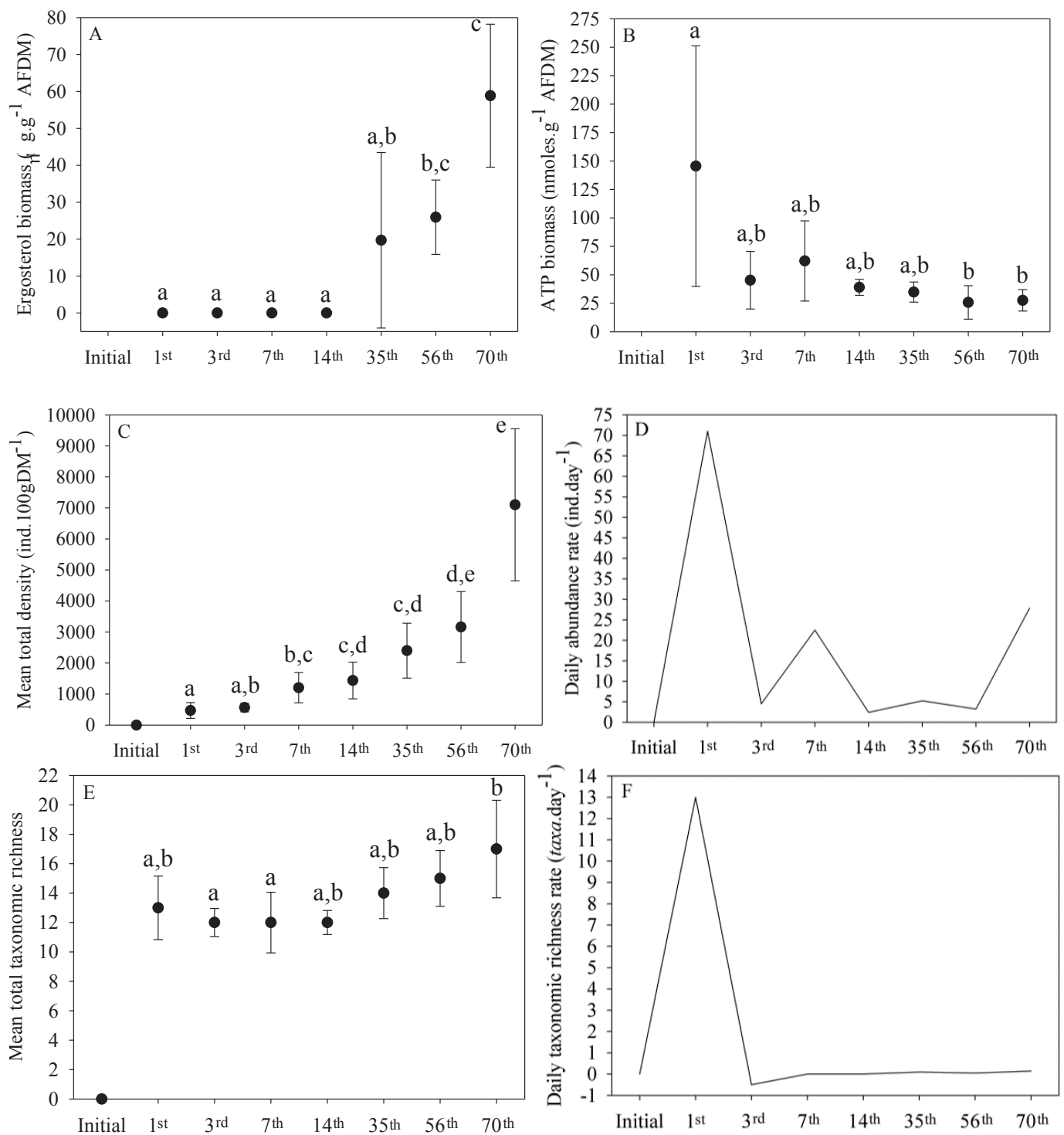

Figure 4. Mean value $(N=4)$ and standard deviations (error bar) of ergosterol concentration (A), ATP concentration (B), total density of invertebrates (C), daily variation rate of colonization of number of individuals (abundance) of invertebrate fauna (ind.day ${ }^{-1}$ ) (D), total taxonomic richness (at large group level) (E), and daily variation rate of taxon colonization (richness) of invertebrate fauna (taxa.day-1) (F) in the remaining dry mass of E. azurea leaves on Barbosa Lake in successive sampling times (number of experiment days) from April to July 2013. (Note the different scales). Sampling times with at least one similar letter present no significant differences (Tukey test; $\mathrm{p} \leq 0.05$ ). Tukey's test was not done to daily variation rate ( $\mathrm{D}$ and $\mathrm{F}$ ). 
other hand also present statistically significant differences in time ( $\mathrm{F}=3.48 ; \mathrm{p}=0.0184)$. Thirteen taxa were recorded one day after the experiment was set up (Fig. 4E). There was a decrease in richness on the $3^{\text {rd }}$ day in relation to the $1^{\text {st }}$ day, which resulted in a negative mean daily rate of colonization (Fig. 4F). In the two successive periods, the richness was low and gradually increased from the $14^{\text {th }}$ day up to the end of the experiment; however, the colonization rate did not vary substantively (Fig. 4F). This result is evidenced by the linear regression that presented a low $\mathrm{R}^{2}$ value (0.0942).
Among the large groups recorded, class Insecta had the greatest density, except in the sampling periods corresponding to days 1, 3 and 7, when Crustacea predominated (Fig. 5). The relative abundance of taxa Diptera and Cladocera varied the most. On the $3^{\text {rd }}$ day, Diptera corresponded to $16.5 \%$ and Cladocera to $47.4 \%$ of the total abundance of the invertebrate community, being the smallest and the greatest values of these taxa, respectively. On the other hand, the opposite was observed on day 35, when the Diptera relative abundance was the greatest $(60.0 \%)$ and that of Cladocera was the smallest (6.9\%) (Fig. 5).

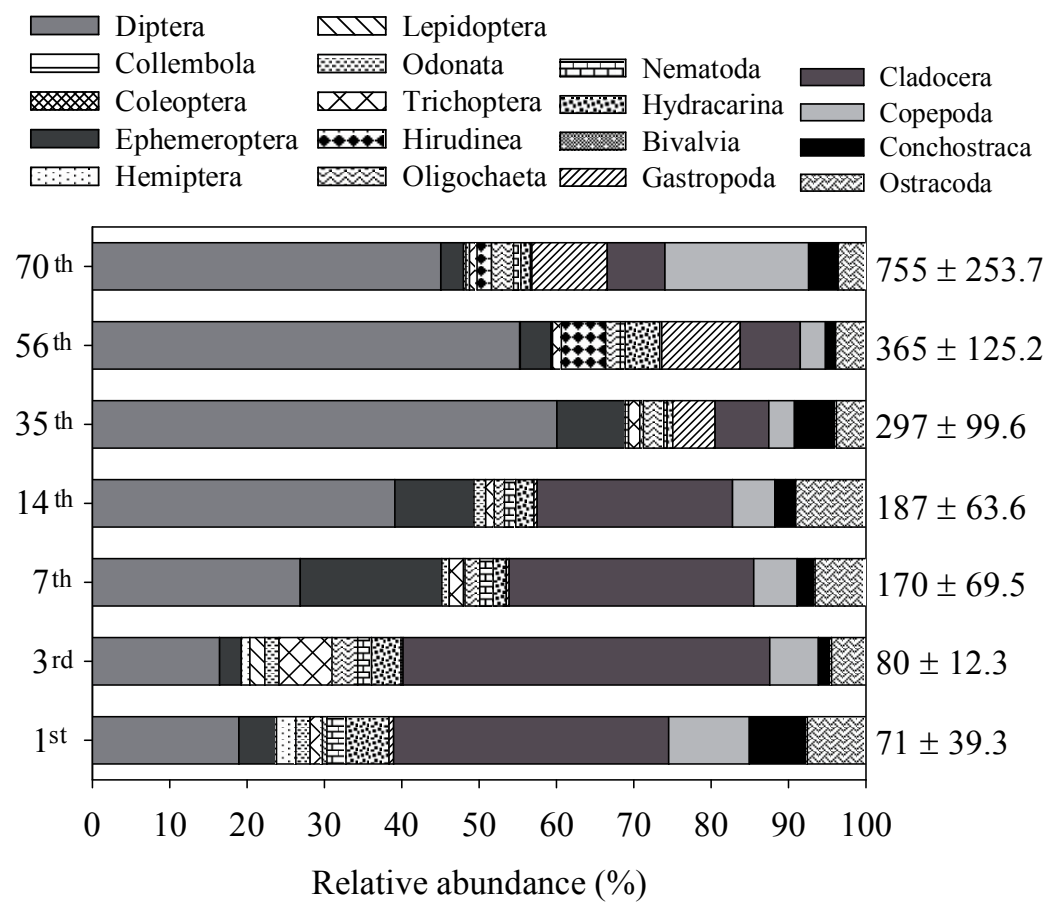

Figure 5. Mean value $(\mathrm{N}=4)$ and standard deviations $( \pm)$ of relative abundance $(\%)$ and total abundance (values presented to the right) of invertebrates associated with E. azurea leaf detritus on Barbosa Lake at successive sampling times (number of experiment days) from April to July 2013.

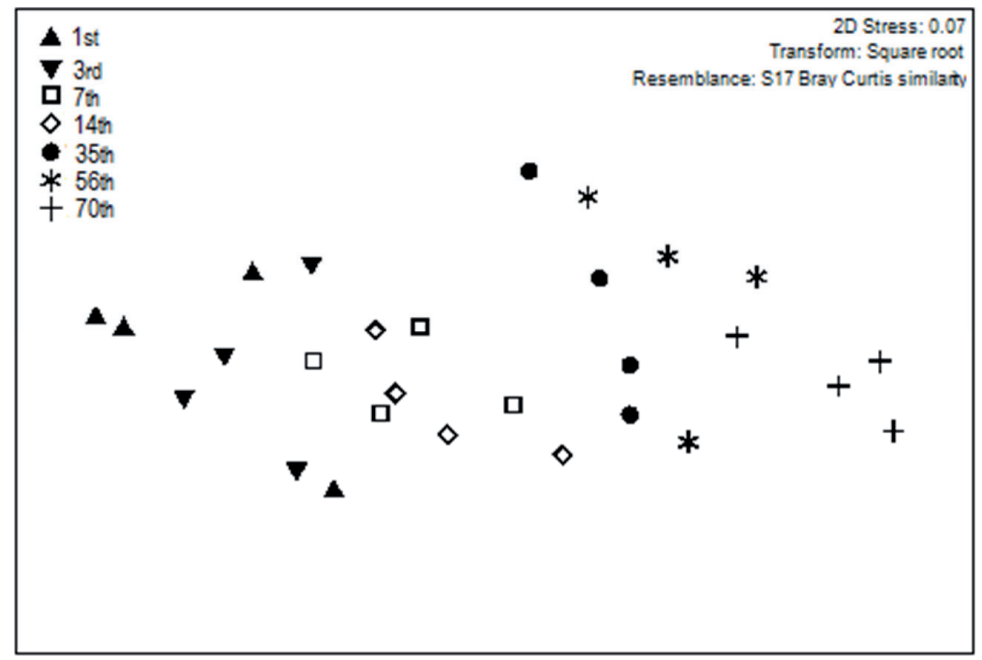

Figure 6. Non-Metric Multidimensional Scaling (NMDS) of densities (ind. $100 \mathrm{gDM}^{-1}$ ) of invertebrates associated with E. azurea leaf detritus at large group levels on Barbosa Lake on sampling days from April to July 2013. 
Table 3. Density of taxa associated with detritus of E. azurea leaves on Barbosa Lake with the greatest number of significant Spearman correlations $(\mathrm{p} \leq 0.05)$ with abiotic and biotic variables in successive sampling times between April and July 2013(-/+ signals = negative and positive correlations, and below the $\mathrm{R}$ values).

\begin{tabular}{|c|c|c|c|c|c|c|c|c|c|}
\hline \multirow{2}{*}{ Groups } & \multicolumn{9}{|c|}{ Variables } \\
\hline & $E R G$ & $A T P$ & $B I O$ & $W T$ & $O S M$ & $T N$ & $T$ & $D N$ & $D P$ \\
\hline Total density & $\begin{array}{c}+ \\
+ \\
0.824\end{array}$ & $\begin{array}{c}- \\
0.444\end{array}$ & $\begin{array}{c}- \\
0.882\end{array}$ & $\begin{array}{c}- \\
0.732\end{array}$ & & $\begin{array}{c}+ \\
0.601\end{array}$ & & $\begin{array}{c}+ \\
+ \\
0.394\end{array}$ & $\begin{array}{c}- \\
0.418\end{array}$ \\
\hline Richness & $\stackrel{+}{+} 0.668$ & & $\begin{array}{c}- \\
0.624\end{array}$ & $\begin{array}{c}- \\
0.540\end{array}$ & & & & & \\
\hline Diptera (pupae) & $\stackrel{+}{+} 0.539$ & & $\begin{array}{c}- \\
0.623\end{array}$ & & & & $\begin{array}{c}- \\
0.474\end{array}$ & $\stackrel{+}{+} 0.374$ & $-\overline{-}$ \\
\hline Chironominae & $\begin{array}{c}+ \\
0.782\end{array}$ & $-\overline{-}$ & $\begin{array}{c}- \\
0.891\end{array}$ & $\begin{array}{c}- \\
0.773\end{array}$ & $\begin{array}{c}+ \\
0.381\end{array}$ & $\begin{array}{c}+ \\
0.761\end{array}$ & & & $0 . \overline{4} 9$ \\
\hline Tanypodinae & $\begin{array}{c}+ \\
0.802\end{array}$ & - & - & - & & $\begin{array}{c}+ \\
0.589\end{array}$ & & $\begin{array}{c}+ \\
0.443\end{array}$ & $\begin{array}{c}- \\
0.494\end{array}$ \\
\hline Orthocladiinae & $\stackrel{+}{0.654}$ & & $\begin{array}{c}- \\
0.523\end{array}$ & & & & & & \\
\hline Ceratopogonidae & $\begin{array}{c}+ \\
0.519\end{array}$ & & & & & & & & \\
\hline Culicidae & $\begin{array}{c}+ \\
0.481\end{array}$ & & $\begin{array}{c}- \\
0.377\end{array}$ & & & & $\begin{array}{c}- \\
0.429\end{array}$ & & \\
\hline Coleoptera & $\begin{array}{c}+ \\
0.375\end{array}$ & & & & & & & & \\
\hline Ephemeroptera & $\begin{array}{c}+ \\
0.470\end{array}$ & & $\overline{-}$ & $\begin{array}{c}- \\
0.540\end{array}$ & & & $\overline{-}-\overline{443}$ & $\stackrel{+}{+} 0.568$ & \\
\hline Hemiptera & & & & & $\begin{array}{c}- \\
0.466\end{array}$ & $\begin{array}{c}- \\
0.464\end{array}$ & & $\begin{array}{c}- \\
0.436\end{array}$ & \\
\hline Odonata & & & & & $\begin{array}{c}- \\
0.417\end{array}$ & & & & \\
\hline Trichoptera & $\begin{array}{c}+ \\
0.481\end{array}$ & & $\begin{array}{c}- \\
0.444\end{array}$ & & & & & & \\
\hline Hydracarina & $\begin{array}{c}+ \\
0.623\end{array}$ & $\begin{array}{c}- \\
0.429\end{array}$ & $\begin{array}{c}- \\
0.761\end{array}$ & & & $\begin{array}{c}+ \\
0.438\end{array}$ & & & $\begin{array}{c}- \\
0.392\end{array}$ \\
\hline Hirudinea & $\begin{array}{c}+ \\
0.643\end{array}$ & $-\overline{-}$ & $\begin{array}{c}- \\
0.578\end{array}$ & $\begin{array}{c}- \\
0.504\end{array}$ & & & & & \\
\hline Oligochaeta & $\begin{array}{c}+ \\
0.592\end{array}$ & & $\begin{array}{c}- \\
0.677\end{array}$ & $\begin{array}{c}- \\
0.468\end{array}$ & $\begin{array}{c}+ \\
0.423\end{array}$ & $\stackrel{+}{+} 0.538$ & & & $\begin{array}{c}- \\
0.375\end{array}$ \\
\hline Bivalvia & $\stackrel{+}{+} 0.532$ & & $\begin{array}{c}- \\
0.581\end{array}$ & & & & & & $\begin{array}{c}- \\
0.414\end{array}$ \\
\hline Gastropoda & $\begin{array}{c}+ \\
0.772\end{array}$ & & $\begin{array}{c}- \\
0.808\end{array}$ & $\begin{array}{c}- \\
0.634\end{array}$ & & $\begin{array}{c}+ \\
0.617\end{array}$ & & & $\begin{array}{c}- \\
0.493\end{array}$ \\
\hline Cladocera & & & & & $\begin{array}{c}- \\
0.477\end{array}$ & & $\begin{array}{c}- \\
0.734\end{array}$ & $\begin{array}{c}+ \\
0.448\end{array}$ & \\
\hline Copepoda & $\stackrel{+}{+} 0.455$ & & $\begin{array}{c}- \\
0.494\end{array}$ & & & & $\begin{array}{c}- \\
0.623\end{array}$ & $\begin{array}{c}+ \\
0.467\end{array}$ & \\
\hline Conchostraca & $\begin{array}{c}+ \\
+ \\
0.489\end{array}$ & & $\begin{array}{c}- \\
0.461\end{array}$ & & & & $\begin{array}{c}- \\
0.377\end{array}$ & & \\
\hline Ostracoda & $\begin{array}{c}+ \\
0.435\end{array}$ & & $\begin{array}{c}- \\
0.567\end{array}$ & $\begin{array}{l}- \\
0.456\end{array}$ & & & & & \\
\hline Nematoda & $\begin{array}{c}+ \\
0.537\end{array}$ & & $\begin{array}{c}- \\
0.412\end{array}$ & & & & & & \\
\hline
\end{tabular}

Insecta $(30.75 \%)$ and Crustacea $(45.85 \%)$ were the main taxonomic groups responsible for the similarity within the clusters formed at each sampling time according to the SIMPER analysis. In the beginning, Crustacea contributed more significantly than Insecta; however, from day 7 on, Insecta contributed more to the formation of NMDS clusters (Fig. 6).

The variables with the greatest number of significant correlations $(\mathrm{p} \leq 0.05)$ for the different invertebrate taxa were er- gosterol and the E. azurea leaf detritus remaining biomass (Table 3).

\section{Discussion}

To evaluate the energy flow, the taxonomic composition pattern and role in the organic matter degradation process is important to further the understanding of the metabolism of continental aquatic ecosystems (Gonçalves et al. 2003). 
Aquatic insects that consume detritus inevitably feed on the microbial community (Lancaster and Downes 2013). The variable with the greatest number of positive correlations with large groups of invertebrates was fungal biomass. However, the total biomass of the microbial community (including fungi, bacteria and protozoa) present in E. azurea leaf detritus presented negative correlations with the invertebrates' density. This is an unexpected result, considering that microorganisms are beneficial to the invertebrate community associated with plant organic matter decomposition, as they improve the palatability and nutritional value of the food resource available (Stripari and Henry 2002). So, the negative correlation of ATP with the densities of different taxa found in this study was probably spurious and due to the ATP peak observed on the $1^{\text {st }}$ day.

Colonization by the microbial community during the decomposition of detritus of leaves from the riparian zone of a tropical stream showed that fungi predominate in the initial stages of decomposition and that bacteria are more abundant when the leaves are already fragmented and soft (Abelho et al. 2005). Abelho (2009) also reported that bacteria become gradually more important in the degradation of plant organic matter as the detritus particles become smaller. However, other studies have shown that in the initial stages of decomposition, the density of bacteria is greater than that of fungi, which become more abundant in intermediate and final stages of decomposition (Gonçalves et al. 2007). Greater densities of bacteria in the beginning of the decomposition process also were pointed by Gaur et al. (1992), Mille-Lindblom and Tranvik (2003), and Quintão et al. (2013). As in the present study, Gaur et al. (1992) found that the colonization of Eichhornia crassipes detritus by fungi was observed only on the $35^{\text {th }}$ day of decomposition and that the contribution of bacteria to the degradation of plant organic matter was much smaller after 67 days. A study by Mille-Lindblom and Tranvik (2003) showed a strong antagonism between fungi and bacteria in the decomposition of macrophyte Phragmites culms. The fungal biomass was approximately 12 times greater in the absence of bacteria and the bacterial biomass nearly doubled in the absence of fungi. This antagonism is an important controlling factor of colonization and growth of the microbial community in aquatic plant detritus (Mille-Lindblom and Tranvik 2003). They also reported that the growth of fungi can be inhibited by both the presence of some bacterial extracellular compound and the competition for substrate colonization and nutrients.

The composition and activity of microbial communities are influenced by the availability of nitrogen and phosphorus in the environment or in the plant detritus, as well as by their ratio (N/P) (Güsewell and Gessner 2009). In a study on decomposition and microorganism colonization in microcosm experiments, they also observed that bacteria were more abundant when the N/P ratio was low, in opposition to fungi. In our study, a similar result was found only on the $1^{\text {st }}$ sampling day, when the lowest N/P ratio and the largest ATP concentration were observed. However, even with high N/P ratios at the other sampling times, in both E. azurea leaf de- tritus and water inside the macrophyte stands, ergosterol was detected only from the $35^{\text {th }}$ day on.

The fungal colonization of plant detritus can also be influenced by plant chemical defenses against herbivores and pathogens, considering that many of them remain active after plant senescence (Graça and Canhoto 2006). In a comparison of the chemical composition of fresh biomass from different species of macrophytes, Henry-Silva et al. (2001) observed that the largest polyphenol contents were recorded in E. azurea, with values between 4.00 and 5.00 UDO.gDM1. However, these values are very low when compared to the values reported by Stripari and Henry (2002) for the decomposition of this macrophyte. Initially, the polyphenol content was at $33.00 \mathrm{UDO}^{\mathrm{gDM}}{ }^{-1}$ and then it decreased to $\cong 16.00$ UDO.gDM-1 midway through the experiment and presented

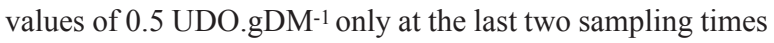
(Stripari and Henry 2002). Mormul et al. (2006) suggest that the leaves of E. azurea contain some compound that limits their "exploitation" in the initial stages of decomposition. Based on these reports, we conclude that in our study the initial composition of the detritus and the presence of allelochemicals, especially polyphenols, may have affected the colonization of the detritus by microorganisms during the decomposition process.

The initial chemical composition of the detritus is also related to the leaching rate, considering that high levels of hydrosoluble substances are released during the decomposition of aquatic macrophytes (Bianchini, Jr. et al. 2010). In low leaching plant detritus, such as the one investigated in this study, fungal colonization may be delayed (Bärlocher 1997). Therefore, the small mass loss observed in this experiment may also have contributed to the absence of ergosterol at most of the sampling times.

Aquatic hyphomycetes are the most important and the best studied decomposing fungi present in streams (Gulis and Suberkropp 2007). However, most fungi found in lotic environments differ from those in lentic environments (Wong et al. 1998). Studies of fungal colonization of plant detritus in lakes and reservoirs are still scarce. Furthermore, most of the studies in the literature deal with fungal colonization in litter bags with leaves from riparian forests. In these studies, fungi, especially hyphomycetes, are influenced by a number of factors that determine variations in their abundance, development and activity, as for example, the chemical composition and texture of leaves from different species of arboreal plants (Sales et al. 2015). Very little is known about the biology and ecology of these organisms during the decomposition of aquatic macrophytes in lentic ecosystems, thus driving the need for further investigation.

However, the fungal biomass obtained in this study stood out for its large number of positive correlations with the densities of various invertebrate taxa, while the biomass of remaining detritus of E. azurea leaves showed the greatest number of negative correlations with the density and ecologic attributes of the taxa. On the $56^{\text {th }}$ and $70^{\text {th }}$ sampling days, the detritus mass increased and the invertebrate density values continued to rise throughout the experiment. 
The increase in E. azurea biomass at the final sampling times can be attributed to the adherence of organic matter to the remaining plant material. Filamentous algae from the Desmidium sp. genus were very abundant in Barbosa Lake. As one of the objectives of this study was also to analyze the microbial community associated with leaf detritus, the remaining plant material was carefully washed so as not to remove microorganisms together with the aquatic invertebrates. Therefore, we believe that filamentous algae were not completely removed and that this is why the biomass increased at the end of the experiment.

Analysis of the percent mass loss of E. azurea observed in this study reveals that its decomposition ratio was very slow in comparison to others reported in the literature (Pagioro and Thomaz 1998, Stripari and Henry 2002, Padial and Thomaz 2006, Cunha-Santino et al. 2010, Martins et al. 2011, Bianchini Jr. et al. 2014). In contrast, the half-life $\left(t_{1 / 2}=468\right.$ days) calculated up to the $35^{\text {th }}$ day of incubation was similar to that reported by Cunha-Santino et al. (2010) for refractory fractions of E. azurea $\left(\mathrm{t}_{1 / 2}=385\right.$ to 462 days $)$ in the laboratory. Taylor and Bärlocher (1996) analyzed leaching from dry leaves at room temperature and fresh leaves from different tree species and found that leaf drying had various effects, such as an increase in mass loss due to leaching for most species, leaching reduction for some species or no measurable effect for others. Leaf air-drying affected mass loss significantly (Taylor 1998); however, the degree and direction of change varied greatly and were unpredictable (Taylor and Bärlocher 1996). In this study, probably one of the greatest factors of mass loss in the beginning of the experiment was the type of leaf treatment, as it may have delayed leaching. A small initial decomposition rate was also observed for $E$. azurea by Pagioro and Thomaz $(1998,1999)$ and Padial and Thomaz (2006). As in the present study, the authors also attributed this result to the method used with senescent macrophyte leaves dried naturally. Since aquatic plants generally begin to decompose at the senescence stage, part of the labile compounds may have been lost even before incubation in water (Padial and Thomaz 2006).

Among the aquatic system abiotic variables that determine decomposition, water temperature plays an important role. During hot periods, macrophyte decomposition is expected to be greater as a result of microbial activity (Carvalho et al. 2005). These authors observed a fast decomposition rate for Egeria najas between 17 and $27^{\circ} \mathrm{C}$. In this study, the water temperature varied between 28 and $19{ }^{\circ} \mathrm{C}$, with greater values in the beginning of the experiment, also characterized by small mass plant loss. Therefore, the increase in water temperature seems not to have influenced the result obtained greatly. Dissolved oxygen is another important controlling factor of macrophyte decomposition (Bianchini Jr. et al. 2010 and 2014). The oxidation and decomposition of labile fractions of Pistia stratiotes were greater with high availability of oxygen in the water (Bianchini Jr. et al. 2010), such as happened with the refractory fractions of E. azurea (CunhaSantino et al. 2010, Bianchini Jr. et al. 2014). Anoxic or low oxygenation conditions were not observed in this study, possibly as a result of the presence of a high density of periphytic algae and the proximity to the water surface. However, even in favorable aerobic conditions, the decomposition rate was low.

Plant decomposition and nutrient cycling in aquatic and terrestrial environments are also strongly influenced by biodiversity (Handa et al. 2014). The leaf detritus decomposition rate, for example, can be accelerated by a great diversity of associated decomposing microorganisms since they are efficient in the degradation of plant organic matter (Gessner et al. 2010). As to the biomass, fungi play a more relevant role than bacteria, which contribute more to the microbial respiration rate (Abelho et al. 2005). A study on the patterns of enzymes produced by the community of microorganisms associated with and acting on the degradation of detritus from an emerged macrophyte showed that fungi growing in the absence of bacteria have a great capacity of decomposition of polymers, such as lignin, cellulose and hemicellulose (Romaní et al. 2006). They also reported the absence of enzymes key to the degradation of lignin and cellulose in the presence of bacteria alone. According to these reports, we suggest that the "absence" of fungi in the initial sampling times associated with the ATP peak contributed to the low decomposition rate observed.

Although the variation of the decomposition rate between sampling times was small, significant differences were observed in the density of invertebrate groups over time (Fig. 4C). According to the SIMPER analysis Insecta (mainly Chironomidae) and Crustacea (mainly Cladocera) were the main taxonomic groups in this study. The colonization of decomposing plant organic matter by invertebrates is related to their feeding habits, which may be ingestion of detritus or predation on invertebrate detritivores by organisms from higher trophic levels (Lancaster and Downes 2013). Chironomidae has generalist strategy to obtain food, since most taxa in this group are omnivorous (Berg 1995, Galizzi et al. 2012) and also consume a large amount of detritus (Henriques-Oliveira et al. 2003, Silveira et al. 2013, Saito and Fonseca-Gessner 2014). In macrophyte decomposition experiments, detritus is obviously the most abundant food resource. This also explains the great density of Chironomidae observed in decomposition studies (Gonçalves et al. 2004, Mormul et al. 2006, Carvalho et al. 2015, Albertoni et al. 2018).

Chydoridae family (Cladocera) primarily feed unselectively on periphyton and detritus in lakes (Rantala et al. 2016). Some cladocerans taxa of Chydoridae family (e.g., Alona spp., Chydorus spp.) preferred inhabit at the littoral aquatic vegetation zone (Ali et al. 2007, Debastiani-Júnior et al. 2016), region characterized by a large amount of organic matter (periphyton and detritus). The high abundance of Cladocera in the present study may be due to habitat type and food availability.

The community total density increased since the beginning of the experiment. Some related studies report similar results (Stripari and Henry 2002, Gonçalves et al. 2003, Quintão et al. 2013); however, others report a decrease in density at the end of the experiment (Gonçalves et al. 2004, Silva et al. 2011). The increasing invertebrate density observed in this study may be related to the low decomposition rates as 
the substrate is more stable when the process is slower and consequently, the biological relations become more complex and the probability of colonization of the detritus by a larger number of individuals is greater (Gonçalves et al. 2004). In contrast, a decrease in the density at the end of the decomposition process may be related to a lower quality of the substrate as a food resource (Silva et al. 2011) and an increase in predation or competition for the habitat and food resources.

The total invertebrate density on detritus follows an upward curve with increase in the number of individuals from the beginning the experiment, so one of our working hypothesis about ecological attributes of the invertebrate community was partially confirmed. No similarity trend in taxonomic richness and microorganism's biomass was observed during the experiment, refuting another initial hypothesis. Regarding relationship between invertebrate density and biotic and abiotic variables, our working hypothesis was confirmed just for ergosterol and detritus biomass, which have, respectively the highest and the lowest number of positive correlations with invertebrate density.

\section{Conclusion}

The procedures adopted in this experiment sought to reproduce the decomposition of aquatic macrophytes in natural conditions as close as possible. However, the methodological procedures used may have interfered with the dynamics of decomposition of E. azurea, as it was slower than in other studies. Additionally, factors like decreasing water temperature through the experiment, occasional inhibition of microorganism growth by leachate, predominance of an oligotrophic environment and low abrasion due to the environment lentic regime may have contributed to a low decomposition rate of E. azurea (Battle and Mihuc 2000, Grattan and Suberkropp 2001, Sangiorgio et al. 2004, Carvalho et al. 2005, Sangiorgio et al. 2008, Song et al. 2013). However, colonization of the remaining biomass by invertebrates increased with a significant increase in the total density over time as decomposition progressed.

Bedford (2004) reported decreasing $k$ values with decreasing mesh opening of the litter bag resulting from greater access and involvement of invertebrates (larger mesh opening) and retention of detritus fragments (smaller mesh opening). Although litter bags are largely used in the study of plant decomposition, a major criticism of this method is that it reduces microbial activity and access by larger invertebrates, besides altering the water flow regime and light intensity (Carvalho et al. 2005).

Different studies use various methods, which makes data interpretation difficult and raises doubts on variations in results as possibly due to intrinsic detritus, community and study site characteristics or to the study methods used. Therefore, the use of standardized experimental protocols in the study of the decomposition and colonization of macrophytes by invertebrates may further the knowledge in this scientific field and enable a better understanding of combined factors that influ- ence the dynamics of these processes in continental aquatic environments, which still deserve investigation.

Acknowledgements: The authors are grateful to Fundação do Instituto de Biociências - FUNDIBIO for financially supporting this research; to Hamilton Antonio Rodrigues, Joaquim Nunes da Costa and Lucio Miguel de Oliveira for helping in the field, to Laerte José da Silva for the English language revision, to Jorge Laço Portinho and Adriano Fabbro Gandini for helping in statistical analyses and mapping the study area, respectively. The first author is also grateful to Coordenação de Aperfeiçoamento de Pessoal de Nivel Superior (CAPES) for the scholarship received.

\section{References}

Abelho, M. 2005. Extraction and Quantification of ATP as a Measure of Microbial Biomass. In: Graça, M.A.S., F. Bärlocher and M.O. Gessner. (eds.), Methods to Study Litter Decomposition: a Practical Guide. Springer, Dordrecht. pp. 223-229.

Abelho, M., C. Cressa and M. Graça. 2005. Microbial biomass, respiration, and decomposition of Huracrepitans L. (Euphorbiaceae) leaves in a tropical stream. Biotropica, 37(3):397-402.

Abelho, M., 2009. ATP and ergosterol as indicators of fungal biomass during leaf decomposition in streams: a comparative study. International Review of Hydrobiology 94(1):3-15.

Albertoni, E.F., L.U. Hepp, C. Carvalho and C. Palma-Silva. 2018. Invertebrate composition in submerged macrophyte debris: habitat and degradation time effects. Ecología Austral 28:093-103.

Ali, M.M., A.A Mageed and M. Heikal. 2007. Importance of aquatic macrophyte for invertebrate diversity in large subtropical reservoir. Limnologica 37:155-169.

Bärlocher, F., 1997. Pitfalls of traditional techniques when studying decomposition of vascular plant remains in aquatic habitats. Limnetica 13(2):1-11.

Battle, J.M. and T.B. Mihuc. 2000. Decomposition dynamics of aquatic macrophytes in the lower Atchafalaya, a large floodplain river. Hydrobiologia 418:123-136.

Bedford, A.P. 2004. A modified litter bag design for use in lentic habitats. Hydrobiologia 529:187-193.

Berg H.B. 1995. Larval food and feeding behaviour. In: Armitage P.D., P.S. Cranston and L.C.V. Pinder (eds), The Chironomidae: the biology and ecology of non-biting midges, Chapman and Hall, London, pp 136-168.

Bianchini Jr., I, R.H. Silva, M.B. Cunha-Santino and R.S. Panhota. 2010. Aerobic and anaerobic decomposition of Pistia stratiotes leachates from a tropical eutrophic reservoir (Barra Bonita, SP, Brazil). Braz. J. Biol. 70(3):559-568.

Bianchini Jr., I, M.B. Cunha-Santino, J.U. Ribeiro and D.G.B. Penteado. 2014. Implication of anaerobic and aerobic decomposition of Eichhornia azurea (Sw.) Kunth. on the carbon cycling in a subtropical reservoir. Braz. J. Biol. 74(1):100-110.

Boyd, C.E. and C.P. Goodyear. 1971. Nutritive quality of food in ecological systems. Archiv für Hydrobiologie 69(2):256-270.

Carvalho, C., L.U. Hepp, C. Palma-Silva and E.F. Albertoni. 2015. Decomposition of macrophytes in a shallow subtropical lake. Limnologica 53:1-9.

Carvalho, P., S.M. Thomaz and L.M. Bini. 2005. Effects of temperature on decomposition of a potential nuisance species: 
the submerged aquatic macrophytes Egeria najas Planchon (Hydrocharitaceae). Braz. J. Biol. 65(1):51-60.

Clarke, K.R. and R.N. Gorley. 2006. PRIMER v6:User Manual Tutorial. Plymouth: PRIMER-E.

Clarke, K. and R. M. Warwick. 2001. Change in Marine Communities: An Approach to Statistical Analysis and Interpretation. Plymouth: PRIMER-E.

Cunha-Santino, M.B., I. Bianchini Jr. and M.H. Okawa. 2010. The fate of Eichhornia azurea (Sw.) Kunth. detritus within a tropical reservoir. Acta Limnologica Brasiliensia 22(2):109-121.

Dahroug, Z., N.F. Santana and N.F. Pagioro. 2016. Eichhornia azurea decomposition and the bacterial dynamic: an experimenta research. Braz. J. Microbiol. 47:279-286.

Debastiani-Júnior, J.R., L.M.A. Elmoor-Loureiro and M.G. Nogueira. 2016. Habitat architecture influencing microcrustaceans composition: a case study on freshwater Cladocera (Crustacea Branchiopoda). Braz. J. Biol. 76(1):93-100.

Domínguez, E. and H.R. Fernández. 2009. Macroinvertebrados bentónicos sudamericanos. Fund. Miguel Lillo: Tucumán, Argentina.

Galizzi M.C., F. Zilli and M. Marchese. 2012. Diet and functional feeding groups of Chironomidae (Diptera) in the Middle Paraná River floodplain (Argentina). Iheringia 102(2):117-121.

Gaur, S., P.K. Singhal and S.K. Hasija. 1992. Relative contributions of bacteria and fungi to water hyacinth decomposition. Aquatic Bot. 43:1-15.

Gessner, M.O. 2005. Ergosterol as a measure of fungal biomass. In Graça, M.A.S., F. Bärlocher and M.O. Gessner (eds.), Methods to Study Litter Decomposition: A Pratical Guide. Springer, Dordrecht, pp. 189-195.

Gessner, M.O., C.M. Swan, C.K. Dang, B.G. McKie, R.D. Bardgett, D.H. Wall and S. Hättenschwiler. 2010. Diversity meets decomposition. Trends Ecol. Evol. 25(6):372-380.

Golterman, K.L., R.S., Clymo and M.A.M., Ohmstad. 1978. Methods for Physical and Chemical Analysis of Freshwaters. Oxford: Blackwell Scientific Publications.

Gonçalves, J.F. Jr., F.A. Esteves and M. Callisto. 2003.Chironomids colonization on Nymphaea ampla L. detritus during a degradative ecological succession experiment in a Brazilian coastal lagoon. Acta Limnologica Brasiliensia 15(2):21-27.

Gonçalves, J.F. Jr., J.S. França, A.O. Medeiros, C.A. Rosa and M. Callisto. 2006. Leaf breakdown in a Tropical Stream. Internat. Rev. Hydrobiol. 91(2):164-177.

Gonçalves, J.F. Jr., M.A.S. Graça, and M. Callisto. 2007. Litter decomposition in a Cerrado savannah stream is retarded by leaf toughness, low dissolved nutrients and a low density of shredders. Freshwater Biol. 52:1440-1451.

Gonçalves, J.F. Jr., A.M. Santos and F.A. Esteves. 2004. The influence of the chemic Jr.al composition of Typha domingensis and Nymphaea ampla detritus on invertebrate colonization during decomposition in a Brazilian coastal lagoon. Hydrobiologia 527:125-137.

Graça, M.A.S., F. Bärlocher and M.O. Gessner. 2005. Methods to Study Litter Decomposition: a Practical Guide. Springer, Dordrecht.

Graça, M.A.S. and C. Canhoto. 2006. Leaf litter processing in low order streams. Limnetica 25(1-2):1-10

Grattan, R.M. and K. Suberkropp. 2001. Effects of nutrient enrichment on yellow poplar leaf decomposition and fungal activity in streams. J. North Am. Benthol. Soc. 20(1):33-43.

Gulis, V. and K. Suberkropp. 2003. Interactions between stream fungi and bacteria associated with decomposing leaf litter at different levels of nutrient availability. Aquat. Microbial Ecol. 30(2):149157.

Gulis, V. and K. Suberkropp. 2007. Fungi: biomass, production, and sporulation of aquatic hyphomycetes. In: Hauer, F.R. and G.A. Lamberti (eds.), Methods in Stream Ecology. Academic Press, San Diego. pp. 311-325.

Güsewell, S. and M.O. Gessner. 2009. N:P ratios influence litter decomposition and colonization by fungi and bacteria in microcosms. Funct. Ecol. 23:211-219.

Handa, T., R. Aerts, F. Berendse, M.P. Berg, A. Bruder, O Butenschoen, E. Chauvet, M.O. Gessner, J. Jabiol, M. Makkonen, B.G. McKie, B. Malmqvist, E.T.H.M. Peeters, S. Scheu, B. Schmid, J.v. Ruijven, V.C.A. Vos and S. Hättenschwiler. 2014. Consequences of biodiversity loss for litter decomposition across biomes. Nature 509:218-234.

Henriques-Oliveira A.L., J.L. Nessimian and L.F.M. Dorvillé. 2003 Feeding habits of Chironomid larvae (Insecta: Diptera) from a stream in the Floresta da Tijuca, Rio de Janeiro, Brazil. Braz. J. Biol. 63(2):269-281.

Henry, R., 2005. The connectivity of the Paranapanema River with two lateral lakes in its mouth zone into the Jurumirim reservoir Acta Limnologica Brasiliensia 17(1):57-69.

Henry-Silva, G.G., M.M. Pezzato, R.F. Benassi and A.F.M. Camargo. 2001. Chemical composition of five species of aquatic macrophytes from lotic ecosystems of the southern coast of the state of São Paulo (Brazil). Acta Limnologica Brasiliensia 13(2):11-17.

Lancaster, J. and B.J. Downes. 2013. Aquatic Entomology. Oxford, United Kingdom.

Levenspiel, O. 1974. Engenharia das reações químicas. Edgard Blücher, São Paulo.

Mackereth, F.I.H., J. Heron and J.F. Talling. 1978. Water Analysis Some Revised Methods for Limnologists. Freshwater Biological Association, London.

Martins, R.T., L.S. Silveira and R.G. Alves. 2011. Colonization by oligochaetes (Annelida: Clitellata) in decomposing leaves of Eichhornia azurea (SW.) Kunth (Pontederiaceae) in a neotropical lentic system. Annales de Limnologie - Internat. J. Limnol. 47:339-346.

Mille-Lindblom, C. and L.J. Tranvik. 2003. Antagonism between bacteria and fungi on decomposing aquatic plant litter. Microbial Ecol 45:173-182.

Mille-Lindblom, C., H. Fischer and L.J. Tranvik. 2006. Antagonism between bacteria and fungi: substrate competition and a possible tradeoff between fungal growth and tolerance towards bacteria. Oikos 113:233-242.

Mormul, R.P., L.A. Vieira, S. Pressinatte Jr., A. Monkolski and A.M. Santos. 2006. Sucessão de invertebrados durante o processo de decomposição de duas plantas aquáticas (Eichhornia azurea e Polygonum ferrugineum). Acta Scientiarum 28(2):109-115.

Olson, J.S., 1963. Energy storage and the balance of producers and decomposers in ecological systems. Ecology 44:322-331.

Padial, A.A. and S.M. Thomaz. 2006. Effects of flooding regime upon the decomposition of Eichhornia azurea (Sw.) Kunth measured on a tropical, flow-regulated floodplain (Paraná River, Brazil). River Res. Appl. 22:791-801.

Pagioro, T.A. and S.M. Thomaz. 1998. Loss of weight and concentration of carbon, nitrogen, and phosphorus during decomposition of Eichhornia azurea in the floodplain of the upper Paraná river, Brazil. Revista Brasileira de Biologia 58(4):603-608.

Pagioro T.A. and S.M. Thomaz. 1999. Decomposition of Eichhornia azurea from limnologically different environments of the Upper Paraná River floodplain. Hydrobiologia 411:45-51. 
Poi, A.S.G., M.E. Galassi, R.P. Carnevali and L.I. Gallardo. 2017. Leaf litter and invertebrate colonization: the role of macro consumers in a subtropical wetland (Corrientes, Argentina). Wetlands 37(1):135-143.

Press, W.H., S.A. Teukolsky, W.T. Vetterling and B.P. Flannery. 2007. Numerical Recipes, the Art of Scientific Computing. Cambridge University Press, New York.

Quintão, J.M.B., R.S. Rezende and J.F. Gonçalves. 2013. Microbial effects in leaf breakdown in tropical reservoirs of different trophic status. Freshwater Sc. 32(3):933-950.

Rantala, M.V., T.P. Luoto and L. Nevalainen. 2016. Temperature controls organic carbon sequestration in a subartic lake. Scientific Reports 6:1-11.

Romaní, A.M., H. Fischer, C. Mille-Lindblom and L.J. Tranvik. 2006. Interactions of bacteria and fungi on decomposing litter: differential extracellular enzyme activities. Ecology 87(10):2559-2569.

Saito V.S. and A.A. Fonseca-Gessner. 2014. Taxonomic composition and feeding habitats of Chironomidae in Cerrado streams (Southeast Brazil): impacts of land use changes. Acta Limnologica Brasiliensia 26(1):35-46.

Sales, M.A., J.F. Gonçalves, J.S. Dahora and A.O. Medeiros. 2015. Influence of leaf quality in microbial decomposition in a headwater stream in the Brazilian Cerrado: a 1-year study. Microbial Ecol. 69:84-94.

Sangiorgio, F., M. Pinna and A. Basset. 2004. Inter- and intra-habitat variability of plant detritus decomposition in a transitional environment (Lake Alimini, Adriatic Sea). Chemistry and Ecology 20:353-366.

Sangiorgio, F., S. Dragan, I. Rosati, L. Teodorof, M. Staras, L. Georgescu and Basset, A. 2008. Decomposition of reed swamp detritus in the Danube Delta: a case study of four eutrophic systems. Transitional Waters Bulletin 2(4):26-27.

Sangiorgio, F., D.S. Glazier, G. Mancinelli and A. Basset. 2010. How can habitat size influence leaf litter decomposition in five midAppalachian springs (USA)? The importance of the structure of the detritivorous guild. Hydrobiologia 654:227-236.
Silva, F.L., H.R.N. Oliveira, S.C. Escarpinati, A.A. Fonseca-Gessner and M.C. Paula. 2011. Colonization of leaf litter of two aquatic macrophytes, Mayaca fluviatilis Aublet and Salvinia auriculata Aublet by aquatic macroinvertebrates in a tropical reservoir. Revista Ambiente and Água 6(1):30-39.

Silveira L.S., R.T. Martins, G.A. Silveira, R.M. Grazul, D.P. Lobo and R.G. Alves. 2013. Colonization by Chironomidae larvae in decomposition leaves of Eichhornia azurea in a lentic system in southeastern Brazil. J. Insect Sci. 13(20):1-13.

Song, N., Z.S. Yan, H.Y. Cai and H.L. Jiang. 2013. Effect of temperature on submerged macrophyte litter decomposition within sediments from a large shallow and subtropical freshwater lake. Hydrobiologia 714:131-144.

Strickland, J.D.H. and T.R.A. Parsons. 1960. Manual of seawater analysis. Bull. Fish. Res. Board Can. 125:1-185.

Stripari, N. de L. and R. Henry. 2002. The invertebrate colonization during decomposition of Eichhornia azurea Kunth in a lateral lake in the mouth zone of Paranapanema River into Jurumirim Reservoir (São Paulo, Brazil). Braz. J. Biol. 62(2):293-310.

Taylor, B.R. 1998. Air-drying depresses rates of leaf litter decomposition. Soil Biol. Biochem. 30(3):403-412.

Taylor, B.R. and F. Bärlocher. 1996. Variable effects of air-drying on leaching losses from tree leaf litter. Hydrobiologia 325:173-182.

Teixeira, C. and M.B., Kutner. 1962. Plankton studies in a mangrove environment. I - First assessment of standing stock and ecological factors. Boletim do Instituto Oceanográfico 12:101-124.

Webster, J.R. and E.F. Benfield. 1986. Vascular plant breakdown in freshwater ecosystems. Annu. Rev. Ecol. Syst. 17:567-594.

Wetzel, R.G., 1975. Limnology. Saunders, Philadelphia.

Wong, M.K.M, T-K. Goh, I.J. Hodgkiss, K.D. Hyde, V.M. Ranghoo, C.K.M. Tsui, W-H. Ho, W.S.W. Wong and T.K. Yuen. 1998. Role of fungi in freshwater ecosystems. Biodivers. Conserv. 7:11871206

Received July 13, 2017

Revised November 30, 2017, December 5, 2017

April 15, 2018

Accepted April 30, 2018 